\title{
Percutaneous Cholecystostomy as an Alternative Treatment Choice for Acute Cholecystitis in Elderly and High-Risk Surgical Patients
}

\section{Akut Kolesistit Tanılı Yaşlı ve Yüksek Cerrahi Riskli Hastalarda Alternatif Bir Tedavi Seçeneği: Perkütan Kolesistostomi}

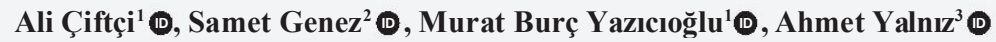 \\ University of Health Sciences, Kocaeli Derince Training and Research Hospital, Department of General Surgery, Kocaeli, Turkey \\ University of Health Sciences, Kocaeli Derince Training and Research Hospital, Department of Radiology, Kocaeli, Turkey
}

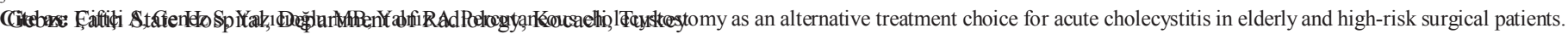
Kocaeli Med J 2021;10(2):125-130.

\section{Abstract}

INTRODUCTION: Acute cholecystitis (AC) is a common surgical emergency. Although surgery is a definite solution, (PC) is effective and safe for the decompression of an infected gallbladder in elderly patients with severe comorbidity or high surgical risk. This study aimed to evaluate the results of percutaneous cholecystostomy PC in elderly or high-risk surgical patients.

METHODS: A total of 41 patients with AC aged over 65 years with American Society of Anesthesiologists scores of III or IV and high surgical risk that had undergone a PC due to comorbidity between February 2017 and December 2019 were included in this study.

RESULTS: Of the 41 patients, $22(53.66 \%)$ were male, and $19(46.34 \%)$ were female. The median age was $76.44 \pm$ 8.46 (range 65-93). The most common comorbidities were cardiovascular diseases (73.17\%) and diabetes mellitus $(51.22 \%)$, and $43.90 \%$ of the patients had a multisystem disease. Either the transhepatic or transperitoneal route was used for the PC. No complications or mortality related to the PC procedure were observed. The average time of tube indwelling was 5 (range $0-12$ ) weeks. Surgery was performed on eight patients $4-6$ weeks after the procedure. Seven patients $(17.1 \%)$ died in the intensive care unit after PC. The mean hospitalization time was $7.20 \pm 6.31$ (range 1-30) days.

DISCUSSION AND CONCLUSION: This study found that PC is an inexpensive, easy-to-apply alternative treatment method that can be safely used in the treatment of elderly patients with $\mathrm{AC}$ who do not respond to medical therapy and have high surgical risk.

Keywords: percutaneous, cholecystostomy, cholecystitis, elderly patient

Öz

GİRIŞ ve AMAÇ: Akut kolesistit yaygın bir cerrahi acildir. Cerrahi tedavi kesin çözüm olmasına rağmen, ciddi komorbiditesi olan veya yüksek cerrahi riski olan yaşlı hastalarda, perkütan kolesistostomi ișlemi enfekte safra kesesinin dekompresyonu için etkili ve güvenlidir. Bu çalışmada, yaşlı veya yüksek riskli cerrahi hastalarda perkütan kolesistostomi (PK) sonuçlarımızı değerlendirmeyi amaçladık.

YÖNTEM ve GEREÇLER: Bu çalışmaya Şubat 2017 ile Aralık 2019 tarihleri arasında ciddi komorbidite ve yüksek cerrahi risk nedeniyle perkütan kolesistostomi uygulanan, 65 yas üstü 41 Akut Kolesistit tanılı hasta dahil edildi.

BULGULAR: Kırkbir hastanın 22'si (\% 53,66) erkek, 19'u (\% 46,34) kadındı. Ortanca yaş $76.44 \pm 8.46(65-93$ aralığında) idi. En sık eșlik eden hastalıklar kardiyovasküler hastalıklar (\%73.17) ve diabetes mellitus (\%51.22) idi ve hastaların \% 43.90'ında multisistem hastalığı vardı. PK işlemi için ya transhepatik yada transperitoneal yol kullanıldı. PK işlemine bağlı herhangi bir komplikasyon veya mortalite gözlenmedi. Ortalama kateter kalma süresi 5 (0-12 arası) haftaydı. Sekiz hastaya işlemden 4-6 hafta sonra cerrahi uygulandı. Yedi hasta takip ve tedavi edildikleri yoğun bakım ünitesinde diğer nedenlerden ex oldu. Ortalama hastanede kalış süresi $7.20 \pm 6.31$ (1-30) gündü.

TARTIŞMA ve SONUÇ: Perkütan Kolesistostomi'nin medikal tedaviye yanıt vermeyen ve yüksek cerrahi riski olan yaşlı hastalarda Akut Kolesistitin tedavisinde güvenle kullanılabilecek ucuz, uygulaması kolay alternatif bir tedavi yöntemi olduğunu düşünmekteyiz.

Anahtar Kelimeler: perkütan, kolesistostomi, yaşlı hasta
Geliş tarihi / Received: 14.06.2021

Kabul tarihi / Accepted:

26.07.2021

Sorumlu Yazar/Corresponding Author: Ali Çiftçi

University of Health Sciences, Kocaeli Derince Training and Research Hospital, Department of General Surgery,

Kocaeli, Turkey draliciftci@hotmail.com ORCID: 0000-0001-8217-575X

S. Genez 0000-0002-1484-4496

M.B. Yazıcıŏglu 0000-0002-2722-2469

A. Yalnız 0000-0003-3253-1554 


\section{INTRODUCTION}

Acute cholecystitis (AC) is an emerging disease that general surgeons frequently encounter and have to treat $(1,2)$. Although it is seen in all age groups, it most frequently occurs in the fourth to eighth decades. The incidence of gallstone disease in the elderly population increases with age and is more common in women (3). Acute cholecystitis is diagnosed in most centers worldwide according to Tokyo Guidelines (2, 4-6). Acute cholecystitis is classified into three grades according to the Tokyo Guidelines: grade I (mild), grade II (moderate), and grade III (severe). Although there is no organ dysfunction accompanying AC in Grades I and II, it is seen in stage III (7). The accepted treatment for AC is surgery. The mortality rate of cholecystectomy is below $1 \%$; however, this is increased to over $50 \%$ in patients with severe comorbid disease or high-risk surgical patients $(3,8)$. Therefore, percutaneous cholecystostomy (PC) may be a treatment option for elderly patients with American Society of Anesthesiologists (ASA) scores of III or IV or high-risk surgical patients due to comorbid disease $(1,2,5$, 9). Percutaneous cholecystostomy can provide permanent treatment and act as a bridge for elective surgery $(1,6,10)$.

\section{MATERIALS AND METHODS}

Between 2017 and 2019, ultrasound-guided PC was applied to patients over 65 years of age and have high surgical risk factors who were hospitalized in our hospital with AC. Medical treatment was initiated first: oral intake was stopped, and third-generation cephalosporins and hydration were started in all patients. Percutaneous cholecystostomy was planned for patients who did not respond to the medical treatment. The patients' data were evaluated retrospectively, but clinically and radiologically confirmed diagnoses were included in the study. All the patients signed an informed consent form. The Tokyo Guidelines criteria were used for the diagnosis and grading of AC. Ultrasound was performed on patients who had pain in the right upper quadrant, a positive Murphy's sign. The accepted radiologically positive signs are thickening of the gallbladder wall ( $\geq 5 \mathrm{~mm}$ ), hydrops of the gallbladder, pericholecystic fluid detected by ultrasound, and ultrasonic Murphy findings. The patients' gender; age; AS A score; comorbidities; clinical course; laboratory findings, particularly white blood cell count (WBC) and C-reactive protein (CRP); radiological examination records; length of hospitalization; elective surgical application rates; and complication and mortality rates were evaluated (see Table 1). Percutaneous cholecystostomy was performed under local anesthesia by two interventional radiologists using ultrasound. The transhepatic route was generally preferred; however, the transperitoneal route was used for patients with severe bleeding disorders.

Table 1 American Society of Anesthesiologists physical status classification system (ASA-PS)

\section{Classification Definition}

ASA I A normal healthy patient

ASA II A patient with mild systemic disease

ASA III A patient with severe systemic disease ASA IV patient with severe systemic disease that
is a constant threat to life

ASA V A moribund patient who is not expected to survive without the operation

ASA VI A declared brain-dead patient whose organs are being removed for donor purposes

\section{Adult Examples, Including, but not Limited to:}

Healthy, non-smoking, no or minimal alcohol use

Mild diseases only without substantive functional limitations. Examples include (but not limited to): current smoker, social alcohol drinker, pregnancy, obesity $(30<\mathrm{BMI}<40)$, well-controlled DM/HTN, mild lung disease

Substantive functional limitations; One or more moderate to severe diseases. Examples include (but not limited to): poorly controlled DM or HTN, COPD, morbid obesity (BMI $\geq 40$ ), active hepatitis, alcohol dependence or abuse, implanted pacemaker, moderate reduction of ejection fraction, ESRD undergoing regularly scheduled dialysis, premature infant PCA $<60$ weeks, history ( $>3$ months) of MI, CVA, TIA, or CAD/stents.

Examples include (but not limited to): recent ( $<3$ months) MI, CVA, TIA, or CAD/stents, ongoing cardiac ischemia or severe valve dysfunction, severe reduction of ejection fraction, sepsis, DIC, ARD or ESRD not undergoing regularly scheduled dialysis Examples include (but not limited to): ruptured abdominal/thoracic aneurysm, massive trauma, intracranial bleed with mass effect, ischemic bowel in the face of significant cardiac pathology or multiple organ/system dysfunction

ARD acute respiratory disease, CAD coronary artery disease, COPD chronic obstructive pulmonary disease, CVA cerebral vascular accident, DIC disseminated intravascular coagulation, DM diabetes mellitus, ESRD end stage renal disease, HTN hypertension, MI myocardial infarction, PCA post-conceptual age

The addition of "E" denotes Emergency surgery: (An emergency is defined as existing when delay in treatment of the patient would lead to a significant increase in the threat to life or body part)

Cited from Hurwitz et al. [9] 


\section{Details of the percutaneous cholecystostomy procedure}

All the patients gave their informed consent for the procedure. The risk of hemorrhage was assessed by checking the full blood count and coagulation profile (i.e., platelet $>$ $50.000 / \mathrm{mm}^{3}$ and an international normalized ratio $[\mathrm{INR}] \leq 1.5$ ), and broad-spectrum IV antibiotics were administered 1-2 hours before the procedure. Under ultrasound guidance, a marker was placed on the skin, indicating the site of transhepatic access to the gallbladder. After applying local anesthetic ( $1 \%$ lidocaine) to the skin and liver capsule, the gallbladder was punctured with an 18 -gauge needle, and an 8 or 10 French pigtail drainage catheter was placed using the Selinger technique. Aspirated material was sent for microbiological culture. To confirm that the catheter was positioned correctly, it was flushed with $5 \mathrm{cc}$ of saline, and fluid motion within the gallbladder was observed. The catheter was flushed and aspirated 3-4 times a day to avoid clogging. After 3-4 weeks, the period expected for patient recovery and tract maturation, the catheter was kept closed for 24 hours, and the patency of the cystic and common ducts was then evaluated by fluoroscopy. The catheter was removed when both cystic and common ducts were confirmed to be patent.

\section{Statistical analysis}

The Statistical Package for the Social Sciences, Version 23 (IBM, IL, US) was used for the data analyses.

\section{RESULTS}

A total of 41 patients diagnosed with $\mathrm{AC}$, of which 22 $(53.66 \%)$ were male, and $19(46.34 \%)$ were female, were included in the study. The mean age of the patients was 76.44 \pm 8.46 (range $65-93$ ), while the mean ages of the males and females were $76.00 \pm 8.76$ and $76.95 \pm 8.30$ years, respectively. All patients had an ASA score of III or IV. The most common comorbidities were cardiovascular diseases (73.17\%) (i.e., congestive heart failure, hypertension, coronary artery disease, etc.) and diabetes mellitus (51.22\%), while $43.90 \%$ of the patients had a multisystem disease. Median WBC count, CRP, INR, and body temperature were $12.77 \times 10^{9} / \mathrm{L}$ (range 6.0 23.90), 209.66 mg/L (range 58-321), 1.28 (range 1-2.03), and $37.7^{\circ} \mathrm{C}$ (range $35.2-41.3$ ), respectively. The transhepatic route was preferred in 33 patients $(80.5 \%)$, and the transperitoneal route was preferred in eight patients $(19.5 \%)$. When the drain was placed in the gallbladder without any complications, it was considered a technical success. Clinical, laboratory, and radiological improvement were accepted as clinical success. During the late period of the procedure, drain malrotation in three patients and an AC attack in one patient were observed, while the drain was dislocated in one patient, and drain occlusion occurred in one patient. Surgery was performed in eight patients after 4-6 weeks. All operations were started laparoscopically, but six of them could be completed laparoscopically. Two patients were converted to open cholecystectomy due to fibrosis in the gallbladder. The mean hospitalization time was $7.20 \pm$ 6.31 (range 1-30) days. No complications or mortality related to the PC procedure were observed (see Table 2). Seven patients $(17.1 \%)$ died in the intensive care unit after PC: one patient in the first month, one patient in the second month, one patient at 20 days, one patient at 25 days, one patient at 9 days, and two patients at 2 days. The mean duration of tube indwelling was 5 (range 0-12) weeks. Eight patients' drains were removed by the general surgeon during the operation, and the other drains were removed by the interventional radiology team after evaluation of the cystic duct opening.

\section{DISCUSSION}

Acute cholecystitis is an emergent condition of surgical presentation that is often encountered and managed either medically or by cholecystectomy $(1,2)$. Gallstones are present in approximately $90 \%$ of cholecystitis cases; however, in $10 \%$ of cases, gallstones are not present (5). Therefore, AC can be divided into two groups: acute calculous cholecystitis (ACC) and acute acalculous cholecystitis (AAC); however, the clinical presentations of ACC and AAC are similar. It is thought that obstruction of the cystic duct by a stone initiates the pathogenesis of ACC. However, the physiopathology of AAC is multifactorial and commonly occurs secondary to bile stasis or ischemia $(5,6$, $11,12)$.

The diagnosis of AC was made by clinical, radiological, and biochemical findings; at least two of these must be present for a diagnosis. Grade III AC was diagnosed by the presence of at least one of the items listed in Table 3 (13). Ultrasonography is routinely used in the diagnosis $(8,14)$. However, computed tomography can be used in addition to ultrasound, particularly in complex cases, such as patients with obesity or abdominal gas distension, and it also provides useful information for evaluating the abdominal organs $(5,6,15)$.

The accepted treatment for AC is surgery. Early surgical treatment is recommended for early hospitalized un-complicated cases (8). However, patients who are admitted late or have comorbid medical conditions are candidates for elective surgery after no response to medical treatment (16-18). In our clinic, we prefer to operate on patients within 72 hours of the onset of the first symptoms. If more than 72 hours have passed since the onset of AC symptoms, we operate 4-6 weeks after the end of medical treatment. Laparoscopic cholecystectomy (LC) has become the accepted gold standard for the operative treatment of gallstone disease. Through the development of laparoscopic instruments and surgical experience, LC is also used safely in the early period of AC $(2,6,19)$. An emergency cholecystectomy is required in patients who do not respond to medical treatment. However, cholecystectomy is high risk in patients with comorbid diseases, especially hypertension and diabetes, and in the elderly (1). Along with antibiotic therapy, PC is usually performed 
Table 1 Demographics, symptoms, diagnostics and comorbidities of patientsn $(n=41)$

\begin{tabular}{|c|c|}
\hline Age & mean \pm Std (range) \\
\hline For all patients & $76.44 \pm 8.46(65-93)$ \\
\hline Male & $76.00 \pm 8.76(65-93)$ \\
\hline Female & $76.95 \pm 8.30(66-91)$ \\
\hline Sex & n $(\%)$ \\
\hline Male & $22(53.6)$ \\
\hline Female & $19(46.4)$ \\
\hline Comorbidities & n $(\%)$ \\
\hline Cardiovascular disease plus hypertension & $30(73.17)$ \\
\hline Diabetes mellitus & $21(51.22)$ \\
\hline Chronic obstructive pulmonary disease & $4(9.76)$ \\
\hline Chronic renal failure & $5(12.20)$ \\
\hline Inoperable pancreatic cancer & $1(2.44)$ \\
\hline Kidney cancer & $1(2.44)$ \\
\hline Lung cancer & $1(2.44)$ \\
\hline Peritoneal carcinomatosis of colorectal cancer & $1(2.44)$ \\
\hline Multiple system disease & $18(43.90)$ \\
\hline ASA PS Classification & n $(\%)$ \\
\hline ASA III & $27(65.9)$ \\
\hline ASA IV & $14(34.1)$ \\
\hline Type of acute cholecystitis & n $(\%)$ \\
\hline Calculous & $32(78.05)$ \\
\hline Acalculous & $9(21.05)$ \\
\hline Laboratory findings & mean (range) \\
\hline WBC $\left(\times 10^{9} / \mathrm{L}\right)$ & $12.77(6.0-23.90)$ \\
\hline $\mathrm{CRP}(\mathrm{mg} / \mathrm{L})$ & $209.66(58-321)$ \\
\hline INR & $1.28(1-2.03)$ \\
\hline $\operatorname{AST}(\mathrm{U} / \mathrm{L})$ & $40.22(11-248)$ \\
\hline $\operatorname{ALT}(\mathrm{U} / \mathrm{L})$ & $31.15(6-146)$ \\
\hline r-GTP (GGT) ( U/L) & $124.12(13-899)$ \\
\hline ALP ( U/L) & $165.39(52-1071)$ \\
\hline Total bilirubin (mg/dl) & $1.80(0.4-22.15)$ \\
\hline Amylase ( U/L) & $44.80(10-261)$ \\
\hline Serum creatinine $(\mathrm{mg} / \mathrm{dl})$ & $1.28(0.46-5.51)$ \\
\hline Ultrasound findings & n $(\%)$ \\
\hline Wall thickening & $33(80.49)$ \\
\hline Gallbladder hydrops & $29(70.73)$ \\
\hline Pericholecystic fluid & $17(41.46)$ \\
\hline Sonographic Murphy's sign & $21(51.22)$ \\
\hline Symptoms & n $(\%)$ \\
\hline Abdominal Pain & $37(90.24)$ \\
\hline Fever & $32(78.05)$ \\
\hline Nausea & $28(68.29)$ \\
\hline Vomiting & $24(58.54)$ \\
\hline Murphy's sign & $18(43.90)$ \\
\hline Body temperature & $37.7^{\circ} \mathrm{C}(35.2-41.3)$ \\
\hline Approach & n $(\%)$ \\
\hline Transhepatic & $33(80.49)$ \\
\hline Transperitoneal & $8(19.51)$ \\
\hline Result & n $(\%)$ \\
\hline Elective Cholecystectomy & $8(19.51)$ \\
\hline Laparoscopic & $6(75)$ \\
\hline Laparoscopic converted to open & $2(25)$ \\
\hline Follow without operation & $26(63.41)$ \\
\hline Exitus & $6(14.63)$ \\
\hline
\end{tabular}

$S t d=$ Standard Deviation, ASA PS= American Society of Anesthesiologists physical status classification system, $W B C=$ white blood cell count, $C R P=$ c-reactive protein, INR = International normalized ratio, $A S T=$ aspartate aminotransferase, $A L T=$ alanine aminotransferase, $A L P=$ alkaline phosphatase, $r$-GTP $(G G T)=$ gamma-glutamyl transferase . with local anesthesia under the guidance of ultrasonography as an alternative treatment option, which prepares the patient for elective surgery by providing decompression of the gallbladder in elderly patients who cannot tolerate or refuse surgical treatment due to high risk in surgery $(1,5,6,11,15,19)$. Percutaneous cholecystostomy was first used in the treatment of a patient with gallbladder empyema under ultrasonographic guidance in 1980 (20). Today, it is still being safely used in the treatment of patients with comorbid diseases and high-risk surgical patients. The only disadvantage of this is that the patient is discharged with a drain, which reduces quality of life. For this reason, aspiration of the gallbladder without a drain has been advocated $(11,19)$. Percutaneous cholecystostomy can be performed via the transhepatic or transperitoneal route $(1,8)$. The general preference of our center is the transhepatic route, although the transperitoneal route is preferred for patients with severe bleeding disorders. The technical and clinical success rate of $\mathrm{PC}$ is $>90 \%(8,21,22)$.

Percutaneous cholecystostomy complications can be classified into two groups: early and late complications. Early complications include intra-abdominal bleeding, peritonitis caused by bile leakage, injury of the small intestine and other adjacent organs, pneumothorax, secondary infections caused by catheter dislodgement, and sepsis. Late complications include catheter dislocation from the gallbladder lumen and complete dislocation from the abdomen and $\mathrm{AC}(8,10,13)$. The incidence of these complications is extremely low. In our series, no early complications were observed. However, in one case, the catheter was dislodged two weeks after the patient was discharged. This catheter was not reinserted because the patient was clinically and laboratory stable. Laparoscopic cholecystectomy was performed in the sixth week after PC. One patient developed an AC attack. There was no mortality in any of the patients due to PC, but seven (17.07\%) patients died due to comorbidities. This rate was consistent with the literature.

It has not been identified as an absolute contraindication to $\mathrm{PC}$, but some relative contraindications may restrict the application of the procedure. Coagulopathy is the most common relative contraindication of PC. Therefore, the platelet count and INR value of patients undergoing PC should be $>50.000 / \mathrm{mm}^{3}$ and $<1.5$, respectively. Platelet suspension should be given to patients who have platelet counts $<50,000 / \mathrm{mm}^{3}$ before the PC procedure. Fresh frozen plasma should be given to patients with an INR value $>1.5$ before PC, and it should not be performed until the INR value is $<1.5$ (5). The presence of a very large stone in the gallbladder or porcelain gallbladder can technically complicate the procedure.

In the literature, the reported average length of hospital stay after PC varies $(1-3,19)$. In our study, the mean hospital stay was $7.20 \pm 6.31$ days.

After the PC procedure, the drain should be left in place for at least 3-6 weeks for tract maturation and the cholecystitis condition to disappear $(2,21)$. In the current study, before the 
Table 3 Criteria for grade III AC diagnosis

Cardiovascular impairment Hypotension requiring dopamine or norepinephrine infusion

Neurological impairment Confusional state

Respiratory impairment $\mathrm{PaO}_{2} / \mathrm{fiO}_{2}$ ratio $<300$

Renal impairment Oliguria, serum creatinine $>2 \mathrm{mg} / \mathrm{dL}$

Hepatic impairment INR $>1.5$

Hematological dysfunction Platelets count lower than $100.000 \mathrm{~mm} 3$

Cited from Polistina $F$ et al. [13]

catheters were removed, they were kept closed for 24 hours, and both cystic and common ducts were confirmed to be patent by fluoroscopy by an interventional radiologist. In the patients scheduled for delayed cholecystectomy, the catheter was removed on the operating table by the general surgeon.

Some authors have claimed that elective LC is difficult in patients undergoing PC for gallbladder fibrosis, while others claim that PC acts as a bridge for elective surgery $(6,10)$. Carti and Kutluturk (6), in a series of 50 cases, reported an $80 \%$ conversion to open cholecystectomy rate due to excessive gallbladder fibrosis for 10 patients who underwent elective LC 4-6 weeks after PC application. Therefore, they performed open cholecystectomy for the other 40 patients. However, in our study, we operated on six of the eight (25\%) patients laparoscopically. Although the number of operated cases was limited, we converted to open cholecystectomy in only two patients. Bhatt et al. (15) found a $38 \%$ conversion rate in their study of 145 cases, one of the largest studies conducted in the field of PC. Aroori et al. (10) reported a $31 \%$ conversion rate. Therefore, our results are in line with the literature. We currently prefer PC for patients with comorbid diseases and high surgical risk.

\section{CONCLUSION}

This study found that PC is an inexpensive, easy-to-apply alternative treatment method that can be safely used in the treatment of elderly patients with $\mathrm{AC}$ who do not respond to medical therapy and have high surgical risk due to the presence of comorbid diseases and high ASA scores.

\section{Compliance with ethical standards}

Conflict of interest: Authors declare that they have no conflict of interest. This study was designed as retrospective research, so that informed consent was obtained from all individual participants included in the study, but we have no ethical approval for this article because this is a retrospective study and includes patients before 2020. This article does not contain any studies with human participants or animals performed by any of the authors.

\section{REFERENCES}

1. Gandhi K, Du Plessis R, Klopper J, Kloppers C. Percutaneous Cholecystostomy Placement in Cases of Non-operative
Cholecystitis: A Retrospective Cohort Analysis. World J Surg. 2020. https://doi.org/10.1007/s00268-020-05752-3

2. Tolan HK, Semiz Oysu A, Basak F, Atak I, Ozbagriacik M, Ozpek A, et al. Percutaneous cholecystostomy: A curative treatment modality forelderly and high ASA score acute cholecystitis patients. Ulus Travma Acil Cerrahi Derg. 2017;23(1):34-8.

https://doi.org/10.5505/tjtes.2016.26053

3. Bhandari TR, Shahi S, Bhandari R, Poudel R. Laparoscopic Cholecystectomy in the Elderly: An Experience at a Tertiary Care Hospital in Western Nepal. Surg Res Pract. 2017;2017:8204578.

https://doi.org/10.1155/2017/8204578

4. Yokoe M, Hata J, Takada T, Strasberg SM, Asbun HJ, Wakabayashi G, et al. Tokyo Guidelines 2018: diagnostic criteria and severity grading of acute cholecystitis (with videos). Journal of Hepato-biliary-pancreatic Sciences. 2018;25(1):41-54. https://doi.org/10.1002/jhbp.515

5. Gulaya K, Desai SS, Sato K. Percutaneous Cholecystostomy: Evidence-Based Current Clinical Practice. Semin Intervent Radiol. 2016;33(4):291-6. https://doi.org/10.1055/s-0036-1592326

6. CartiEB,KutluturkK. Shouldpercutaneouscholecystostomy be used in all cases difficult to manage? Ulus Travma Acil Cerrahi Derg. 2020;26(2):186-90. https://doi.org/10.14744/tjtes.2020.73557

7. Okamoto K, Suzuki K, Takada T, Strasberg SM, Asbun HJ, Endo I, et al. Tokyo Guidelines 2018: flowchart for the management of acute cholecystitis. J Hepatobiliary Pancreat Sci. 2018;25(1):55-72. https://doi.org/10.1002/jhbp.516

8. Arslan M, Sözütok S, Akbulut S, Gülek B. Percutaneous gall bladder drainage in ccute cholecystitis patients. Pam Med J. 2019;12(1):127-32.

9. Hurwitz EE, Simon M, Vinta SR, Zehm CF, Shabot SM, Minhajuddin A, et al. Adding Examples to the ASA-Physical Status Classification Improves Correct Assignment to Patients. Anesthesiology. 2017;126(4):614-22. https://doi.org/10.1097/ALN.0000000000001541

10. Aroori S, Mangan C, Reza L, Gafoor N. Percutaneous Cholecystostomy for Severe Acute Cholecystitis: A Useful Procedure in High-Risk Patients for Surgery. Scand J Surg. 
2019;108(2):124-9.

https://doi.org/10.1177/1457496918798209

11. Rassameehiran S, Tantrachoti P, Nugent K. Percutaneous gallbladder aspiration for acute cholecystitis. Proc (Bayl Univ Med Cent). 2016;29(4):381-4. https://doi.org/10.1080/08998280.2016.11929476

12. Itoi T, Coelho-Prabhu N, Baron TH. Endoscopic gallbladder drainage for management of acute cholecystitis. Gastrointest Endosc. 2010;71(6):1038-45.

https://doi.org/10.1016/j.gie.2010.01.026

13. Polistina F, Mazzucco C, Coco D, Frego M. Percutaneous cholecystostomy for severe (Tokyo 2013 stage III) acute cholecystitis. Eur J Trauma Emerg Surg. 2019;45(2):329-36. https://doi.org/10.1007/s00068-018-0912-0

14. Pinto A, Reginelli A, Cagini L, Coppolino F, Stabile Ianora AA, Bracale R, et al. Accuracy of ultrasonography in the diagnosis of acute calculous cholecystitis: review of the literature. Crit Ultrasound J. 2013;5 Suppl 1:S11.

https://doi.org/10.1186/2036-7902-5-S1-S11

15. Bhatt MN, Ghio M, Sadri L, Sarkar S, Kasotakis G, Narsule C, et al. Percutaneous Cholecystostomy in Acute CholecystitisPredictors of Recurrence and Interval Cholecystectomy. J Surg Res. 2018;232:539-46. https://doi.org/10.1016/j.jss.2018.06.051

16. Kao LS, Ball CG, Chaudhury PK, for Members of the Evidence Based Reviews in Surgery G. Evidencebased Reviews in Surgery: Early Cholecystectomy for Cholecystitis. Ann Surg. 2018;268(6):940-2.

https://doi.org/10.1097/SLA.0000000000002867
17. Thangavelu A, Rosenbaum S, Thangavelu D. Timing of Cholecystectomy in Acute Cholecystitis. J Emerg Med. 2018;54(6):892-7. https://doi.org/10.1016/j.jemermed.2018.02.045

18. Ozkardes AB, Tokac M, Dumlu EG, Bozkurt B, Ciftci $A B$, Yetisir F, et al. Early versus delayed laparoscopic cholecystectomy for acute cholecystitis: a prospective, randomized study. Int Surg. 2014;99(1):56-61. https://doi.org/10.9738/INTSURG-D-13-00068.1

19. Haas I, Lahat E, Griton Y, Shmulevsky P, Shichman S, Elad $\mathrm{G}$, et al. Percutaneous aspiration of the gall bladder for the treatment of acute cholecystitis: a prospective study. Surg Endosc. 2016;30(5):1948-51. https://doi.org/10.1007/s00464-015-4419-z

20. Radder RW. Ultrasonically guided percutaneous catheter drainage for gallbladder empyema. Diagn Imaging. 1980;49(6):330-3.

21. Bundy J, Srinivasa RN, Gemmete JJ, Shields JJ, Chick JFB. Percutaneous Cholecystostomy: Long-Term Outcomes in 324 Patients. Cardiovasc Intervent Radiol. 2018;41(6):92834.

https://doi.org/10.1007/s00270-018-1884-5

22. Yeo CS, Tay VW, Low JK, Woon WW, Punamiya SJ, Shelat VG. Outcomes of percutaneous cholecystostomy and predictors of eventual cholecystectomy. J Hepatobiliary Pancreat Sci. 2016;23(1):65-73. https://doi.org/10.1002/jhbp.304 